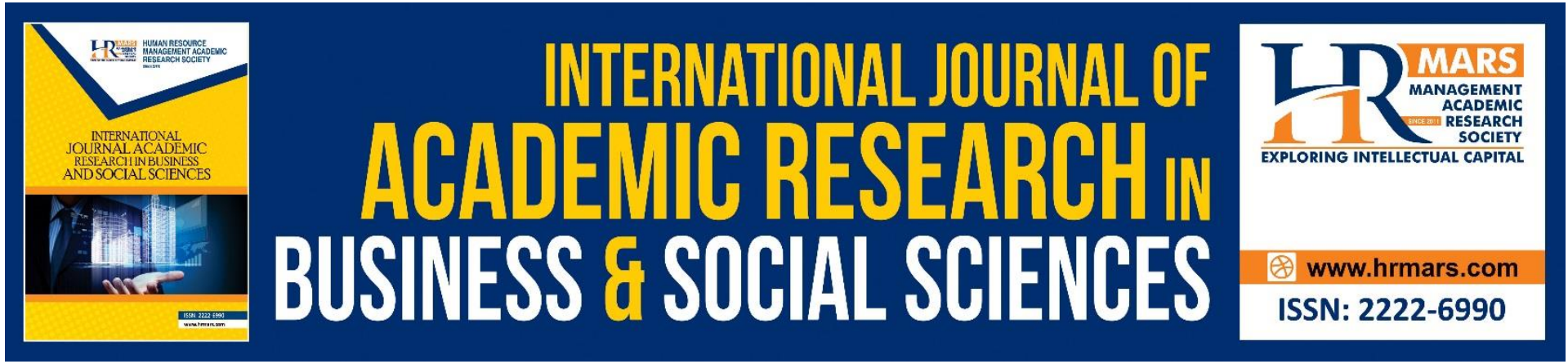

\title{
Competence, Competency, and Competencies: A Misunderstanding in Theory and Practice for Future Reference
}

Muhammad Aiman Arifin

To Link this Article: http://dx.doi.org/10.6007/IJARBSS/v11-i9/11064

DOI:10.6007/IJARBSS/v11-i9/11064

Received: 08 July 2021, Revised: 02 August 2021, Accepted: 29 August 2021

Published Online: 12 September 2021

In-Text Citation: (Arifin, 2021)

To Cite this Article: Arifin, M. A. (2021). Competence, Competency, and Competencies: A Misunderstanding in Theory and Practice for Future Reference. International Journal of Academic Research in Business and Social Sciences, 11(9), 755-764.

Copyright: @ 2021 The Author(s)

Published by Human Resource Management Academic Research Society (www.hrmars.com)

This article is published under the Creative Commons Attribution (CC BY 4.0) license. Anyone may reproduce, distribute, translate and create derivative works of this article (for both commercial and non-commercial purposes), subject to full attribution to the original publication and authors. The full terms of this license may be seen

at: http://creativecommons.org/licences/by/4.0/legalcode

Vol. 11, No. 9, 2021, Pg. 755 - 764

http://hrmars.com/index.php/pages/detail/IJARBSS

JOURNAL HOMEPAGE

Full Terms \& Conditions of access and use can be found at http://hrmars.com/index.php/pages/detail/publication-ethics 


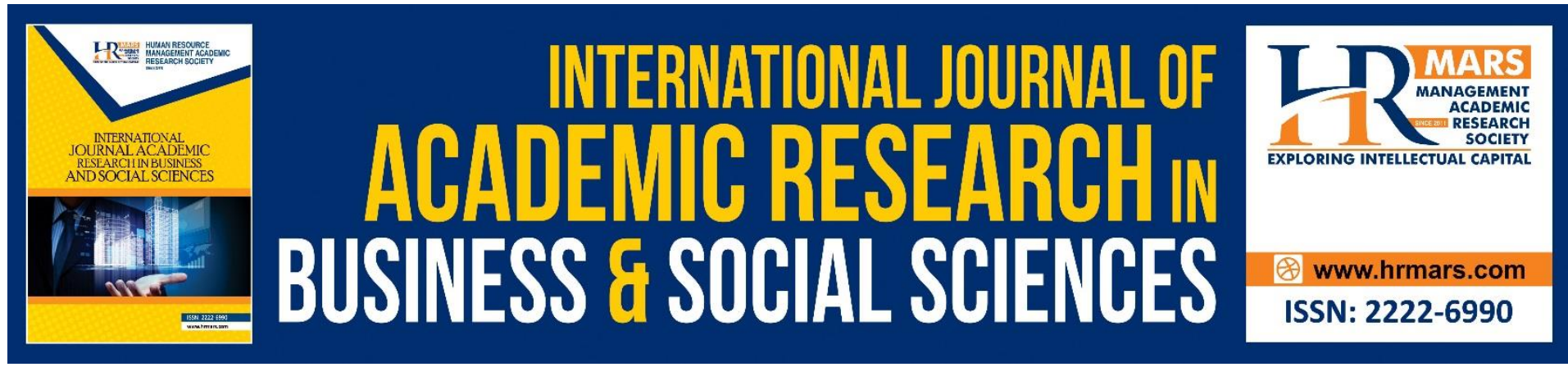

\title{
Competence, Competency, and Competencies: A Misunderstanding in Theory and Practice for Future Reference
}

\author{
Muhammad Aiman Arifin \\ Faculty of Business and Management, Universiti Teknologi MARA Cawangan Perlis, \\ Kampus Arau, 02600 Arau, Perlis, Malaysia \\ Email: aimanarifin@uitm.edu.my
}

\begin{abstract}
The term competence has been widely applied in the field of human resource and management. This term is also used interchangeably with other terminologies, including competency and competencies. Despite their ubiquitous usage in scientific literature, it remains unclear whether all these terminologies pose the same meaning or should be differentiated in theory and practice. Therefore, an enhanced understanding of these terms is contingent upon a firm grasp of their history and importance. This paper consists of three parts: (1) the definition of terms related to competence, competency, and competencies; (2) the categories of competencies; and (3) a proposed diagram to differentiate between these terms. Several academic journals have served as references in obtaining a clear understanding of the differences between the terms competence, competency, and competencies.
\end{abstract}

Keywords: Competence, Competency, Competencies, Human Resource

\section{Introduction}

The competency-based approach has been utilized in organisational settings to measure the levels of employees' knowledge, skills, and abilities. Similar to several other terms, competence and competency also have different versions of meanings from general to specific. Sykes (1980) defined 'competency' and 'competence' as the ability to do a task and these definitions are readily interchangeable with another. In the management literature, the definitions for 'competence' and 'competency' are inconsistent. For instance, Burgoyne (1989) also defined competence as the ability to perform a task.

However, McClelland (1973); Spencer and Spencer (1993) proposed definitions with specific characteristics, such as motives, traits, and skills which are needed to become a superior performer in the organisation. This second definition is in line with the definition offered by Boyatzis (1982), whereby competence is defined as 'an underlying characteristic of a person, which results in effective and/or superior performance in a job.' More confusion can arise due to the different definitions found in dictionaries and from the management context, despite the fact that these terms are often interchanged in the plural form (Moore et al., 2002). 
In addition, the academic context (Dirani et al., 2020; Oberländer et al., 2020) of these terms also differs from the management context (Atan \& Mahmood, 2019), which has left it unclear whether to use lay meaning from the dictionary or to apply the management context. At times, inconsistency may occur in terms of which definition to use in similar contexts between the academic and the management side.

Confusion due to inconsistent meanings may affect the outcome of performance management assessment used by an employer to measure the current level of knowledge, skills, and abilities of an employee (Moore et al., 2002). It is also a possible cause of employee conflict in the organisation, which could reduce teamwork performance, since there is more than one person in a group for a particular department. Thus, this issue needs to be addressed to reduce the multiple definitions of competence, competency, and competencies. This paper will discuss the definition of each term, which could guide future scholars in finding the best way to understand each term for future studies which adopt the competency-based approach.

\section{Literature Review}

From the pioneering work of 'testing for competence rather than for intelligence', McClelland (1973) argued that traditional intelligence or aptitude tests and school grades are less accurate in predicting an individual's job and life performance. Instead, the underlying personal traits and enduring qualitative behaviours, or known as 'competencies', could be used to predict both outcomes more accurately. Since then, many studies have been conducted across various fields of study (Arifin \& Rasdi, 2017; Suhairom et al., 2014), in both local (Huei et al., 2019; Mohd Salleh et al., 2015) and international contexts (Frezza et al., 2018; Kakemam et al., 2020). With many research going on until now (Efimova et al., 2021), a number of misperceptions about the use of the term 'competency' have been found in literature (van der Klink \& Boon, 2003). The subsequent sections of this paper aim to summarise different definitions proposed by different scholars (Richard E. Boyatzis \& Boyatzis, 2008; Cernusca \& Dima, 2007; Dubois \& Rothwell, 2004; Evarts, 1987; Hager et al., 1994; Hoffmann, 1999; McClelland, 1973; Spencer \& Spencer, 1993), as shown in Table 1. This paper will also discuss the most apt definitions for competence, competency, and competencies. 
Table 1. Definition of competencies by authors in competency studies

\begin{tabular}{|l|l|}
\hline \multicolumn{1}{|c|}{ Author(s) } & \multicolumn{1}{|c|}{ Competency Definition } \\
\hline Aiman et al. (2017) & $\begin{array}{l}\text { A set of personal and job knowledge, skills, } \\
\text { abilities, or attitudes for a specific task, job, } \\
\text { or profession within a job performance } \\
\text { scope. }\end{array}$ \\
\hline McClelland (1973) & $\begin{array}{l}\text { A set of traits towards effective or superior } \\
\text { job performance. }\end{array}$ \\
\hline Boyatzis (1982, 2008) & $\begin{array}{l}\text { The relationship between an individual and } \\
\text { superior job performance. }\end{array}$ \\
\hline Spencer \& Spencer (1993) & $\begin{array}{l}\text { Ability and skills gained through training, } \\
\text { and job and life experiences. }\end{array}$ \\
\hline Evarts (1987) & $\begin{array}{l}\text { Managers' underlying characteristics related } \\
\text { to superior performance. }\end{array}$ \\
\hline Hager, Gonczi, and Athanasou (1994) & $\begin{array}{l}\text { The standard or quality as the outcome of an } \\
\text { individual's performance. }\end{array}$ \\
\hline Hoffmann (1999) & $\begin{array}{l}\text { Underlying qualification and attributes of a } \\
\text { person, observable behaviours, and } \\
\text { standard on a person's performance. }\end{array}$ \\
\hline Dubois and Rothwell (2004) & $\begin{array}{l}\text { The combination of knowledge, thought } \\
\text { patterns, skills, and characteristics that } \\
\text { resulted in a successful performance. }\end{array}$ \\
\hline Cernusca and Dima (2007) & $\begin{array}{l}\text { A person's underlying criteria that lead to } \\
\text { individual performance and career } \\
\text { development. }\end{array}$ \\
\hline
\end{tabular}

Source: Adopted from Arifin et al (2017)

Boyatzis (1982); Le Deist and Winterton (2005) mentioned that competency studies are contextual and vital for a specific job position. Different professions require different competency elements to be included in the competency framework. Table 2 summarises the various categories of competencies from different authors. 
Table 2. Levels of competencies

\begin{tabular}{|c|c|}
\hline Author(s) & Classification of Competencies \\
\hline Spencer and Spencer (1993) & $\begin{array}{lll}\begin{array}{l}\text { Competencies } \\
\text { differentiating) }\end{array} & \text { (threshold and } \\
\end{array}$ \\
\hline Arifin et al. (2017) & $\begin{array}{l}\text { Comprehensive competencies (job and } \\
\text { personal competencies) }\end{array}$ \\
\hline Kuijpers et al. (2006) & $\begin{array}{l}\text { Career competencies (functional, } \\
\text { learning, and career) }\end{array}$ \\
\hline Abraham et al. (2001) & $\begin{array}{l}\text { Problem skills, result focused, } \\
\text { leadership, customer oriented, flexible, } \\
\text { team }\end{array}$ \\
\hline Rothwell (2002) & $\begin{array}{lll}\begin{array}{l}\text { Competencies } \\
\text { intermediate) }\end{array} & \text { (foundational and } \\
\end{array}$ \\
\hline Jacob (1989) & Competencies (hard and soft) \\
\hline Prahalad and Hamid (2007) & Competencies (core) \\
\hline Thomas and Sireno (1980) & $\begin{array}{l}\text { Competencies (control, leadership, and } \\
\text { communication) }\end{array}$ \\
\hline Raven and Stephenson (2001) & $\begin{array}{l}\text { Competencies (meaning, relation, } \\
\text { learning, and change) }\end{array}$ \\
\hline Hunt and Wallace (1997) & $\begin{array}{l}\text { Competencies (leadership, strategic } \\
\text { management, administrative, problem } \\
\text { solving) }\end{array}$ \\
\hline Boyatzis (1982) & $\begin{array}{l}\text { Competencies (leadership, HRM, and } \\
\text { goal and action management) }\end{array}$ \\
\hline Le Deist and Winterton (2005) & Competencies (functional) \\
\hline
\end{tabular}

Source: Adopted from Shet et al. (2017)

\section{Misinterpretation}

The term 'competency' is a 'fuzzy' concept (Wong, 2020) which may lead to misinterpretation because the terms 'competence' and 'competency' can be used interchangeably without proper justifications. The first term, competency, is a person's knowledge, skills, and abilities or attitude. The second term, competence, refers to task-oriented behavioural approaches. Table 3 describes the differences between both terms from various perspectives.

\section{The Issues of Definitions}

Competence can be used to refer to areas of work in which the person is competent, the socalled 'areas of competence'. However, when the areas being referred to are the dimensions of behaviour lying behind competent performance, with a meaning that can be regarded as being 'person-related', Woodruffe (1991) recommended that the term 'competency' should be used instead. Similarly, Armstrong (1998) sought to differentiate between 'competence' and 'competency". Armstrong's perspective was that 'competence' describes what people need in order to be able to perform a job well; the emphasis is on doing (perhaps in terms of achieving the desired output). 'Competency', in contrast, defines dimensions of behaviour lying behind competent performance. These are often referred to as behavioural competencies, because they are intended to describe how people behave when they carry out their jobs. The differences between these two terms can seem overly subtle and may be 
disregarded by some. Such a possibility would be unfortunate if realised in the context of performance assessment carried out within an organisation.

Table 3. Comparison between 'competency', 'competence', and 'competencies'

\begin{tabular}{|l|l|l|}
\hline \multicolumn{1}{|c|}{ Competence } & \multicolumn{1}{|c|}{ Competency } & \multicolumn{1}{c|}{ Competencies } \\
\hline Focuses on the results & Focuses on a person's behaviours & $\begin{array}{l}\text { Focuses on more than one } \\
\text { behaviour of a person }\end{array}$ \\
\hline $\begin{array}{l}\text { Describes the features } \\
\text { of the area of work } \\
\text { tasks or job outputs }\end{array}$ & $\begin{array}{l}\text { Describes the attributes of the } \\
\text { person }\end{array}$ & $\begin{array}{l}\text { Describes more than one } \\
\text { attribute of the person }\end{array}$ \\
\hline $\begin{array}{l}\text { Constitutes the } \\
\text { various skills and } \\
\text { knowledge needed for } \\
\text { performing the job }\end{array}$ & $\begin{array}{l}\text { Constitutes the underlying } \\
\text { attribute of a person with } \\
\text { superior work performance }\end{array}$ & $\begin{array}{l}\text { Constitutes underlying } \\
\text { attributes of a person with } \\
\text { superior work performance. }\end{array}$ \\
\hline $\begin{array}{l}\text { Not transferable as } \\
\text { each skill and } \\
\text { knowledge is more } \\
\text { specific to perform } \\
\text { the job }\end{array}$ & $\begin{array}{l}\text { Transferable from one person to } \\
\text { another }\end{array}$ & $\begin{array}{l}\text { Transferable from one } \\
\text { person to another }\end{array}$ \\
\hline $\begin{array}{l}\text { Assessed by } \\
\text { performance on the } \\
\text { job }\end{array}$ & $\begin{array}{l}\text { Assessed in terms of behaviours } \\
\text { and attitude }\end{array}$ & $\begin{array}{l}\text { Assessed in terms of } \\
\text { knowledge, skills, and } \\
\text { abilities }\end{array}$ \\
\hline Task-oriented & People-oriented & People-oriented \\
\hline
\end{tabular}

Source: Adopted from R. Yuvaraj (2011)

As shown in Table 3, there are several differences between 'competency' and 'competence'. However, people tend to use these terms interchangeably when conducting their research. Zemke (1982) suggested that there is still no standard definition for these terms, since they would be based on the different objectives of each study. Along with 'competence' and 'competency', there is also the term 'competencies'. This term reflects on the recognition for an employee who possesses the required knowledge, skills, and abilities required by a specific profession. Coming from this perspective, the following characteristics of these key terms are suggested by Moore et al (2002):

Competence - an area of work supported by an employee's knowledge, skills, and abilities.

Competency - the behaviour(s) supporting an area of work through knowledge, skills, abilities, and attitude.

Competencies - the attributes underpinning a behaviour.

The competence of an employee should be the main concern for a specific task, job, or profession as a reflection of their individual 'competence'. In this context, the results for whether an employee is able to perform a specific competency would be based on their actions against a prescribed standard of competency element and vice versa. When organisations in one country are acquired by organisations from a different country, the 
differences in terminology will cause greater confusion and conflict, for instance, between organizations and countries in Europe and Asia. This definition confuses behaviour (competency) with outcomes, or area of work (competence). In order to gain some clarification from this confusing situation, an analysis of the differences between countries in Europe and Asia was conducted using different models to offer better definitions of the terms competency, competence, and competencies.

This study proposes the following diagram to explain the position for each term. Figure 1 shows four main terms discussed in this paper, namely competent, competency, competence, and competencies. Competent refers to a condition where a person is able to meet the performance criteria set by the organisation. Competence means the ability to meet the performance criteria (knowledge, skills, abilities, attitude, and behaviours). Competency is a set of knowledge, skills, abilities, attitude, and behaviours. Competencies are different sets of knowledge, skills or abilities that are transformed into several competency domains to represent a specific task or profession. It is clear that different terms contain different explanations for each one. This diagram is in line with most of the definitions proposed by previous authors in competency studies (Richard E. Boyatzis \& Boyatzis, 2008; Cernusca \& Dima, 2007; Dubois \& Rothwell, 2004; Evarts, 1987; Hager et al., 1994; Hoffmann, 1999; McClelland, 1973; Spencer \& Spencer, 1993).

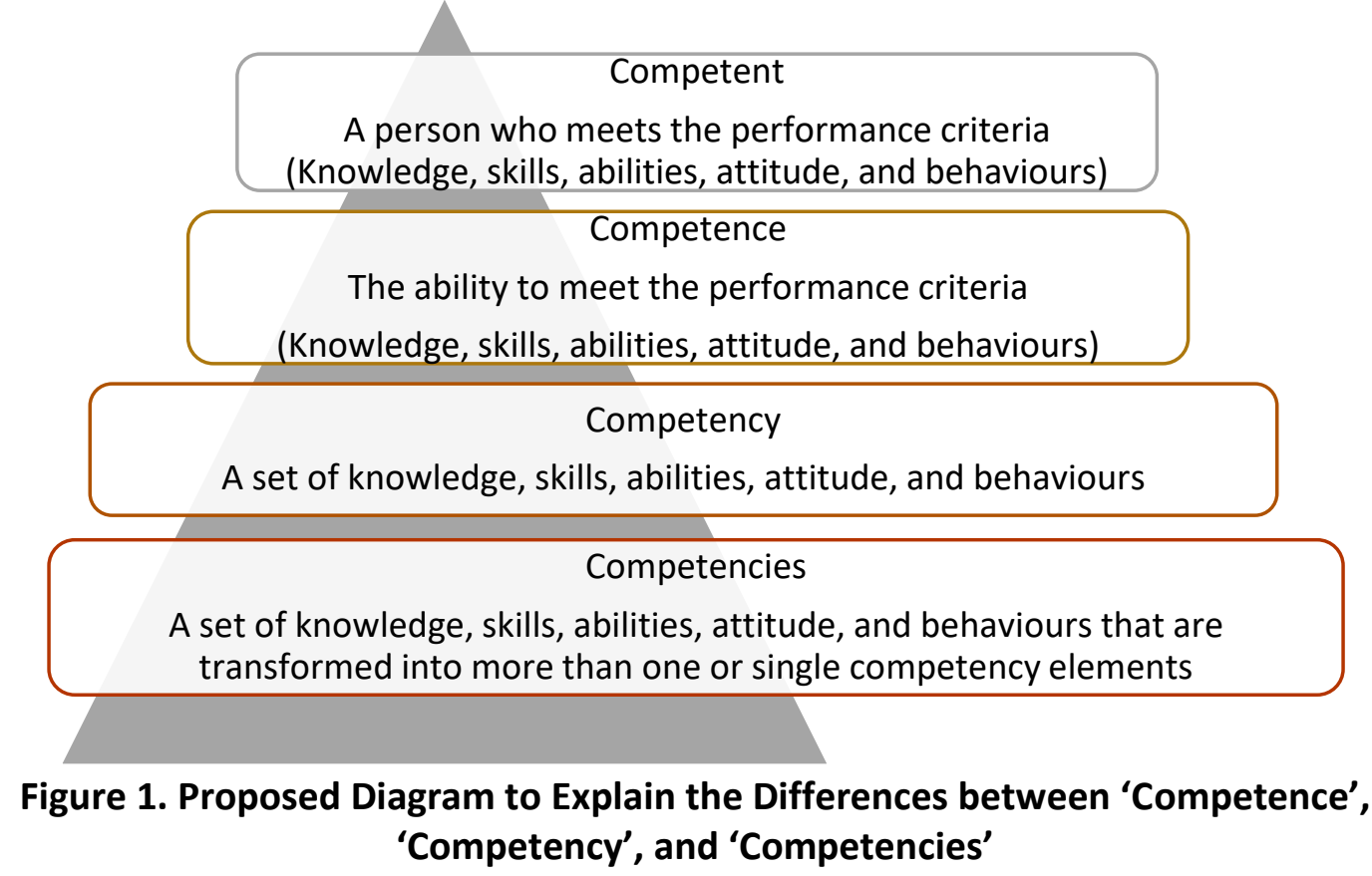

\section{Conclusion}

A number of confusions related to the area of study on competence, competency, and competencies have been highlighted in this paper. Apart from the articles written by McClelland (1973) and Moore et al. (2002), there is no consensus among scholars on how to address the misconceptions regarding the definitions of competence, competency, and competencies. In this paper, a new explanation for each term is addressed by proposing a pyramid diagram that can be used as a guide by other HR and management researchers and scholars concerning the future direction of competency-based assessments. A particular aspect of this diagram is to ensure that the right decision is made by HR departments and researchers when adopting a competency-based approach. It is anticipated that future 
competency studies will further contribute to this debate through the implementation of competency-based approach across various organisational context, profession, and nation. Output from this study can be utilised towards arriving at an overall consensus regarding the right terms to use for the right study or perspectives.

\section{References}

Abraham, S. E., Karns, L. A., Shaw, K., \& Mena, M. A. (2001). Managerial competencies and the managerial performance appraisal process. Journal of Management Development, 20(10), 842-852. https://doi.org/10.1108/02621710110410842

Arifin, M. A., \& Rasdi, R. M. (2017). Addressing Competency Gaps for Vocational Instructor through Competency Model and Instrument for Competency MEasurement. THE 4TH INTERNATIONAL CONFERENCE ON EDUCATIONAL RESEARCH AND PRACTICE (ICERP) 2017 Empowering Education Through Translational Research and Practices, 7(4), 12011216. https://doi.org/10.6007/IJARBSS/v7-i4/2970

Arifin, M. A., Rasdi, R. M., Mohd, M. A., \& Omar, M. K. (2017). Competencies of Vocational Teacher: A Personnel Measurement Framework. 7, 147-164. https://doi.org/10.6007/IJARBSS/v7-i14/3659

Atan, B. J., \& Mahmood, N. H. N. (2019). The role of transformational leadership style in enhancing employees' competency for organization performance. Management Science Letters. https://doi.org/10.5267/j.msl.2019.7.033

Boyatzis, R. E. (1982). Competence and job performance. Competence and Performance, 1039. https://doi.org/Samsung/Academico/Material Didatico MKZ/GC

Boyatzis, R. E., \& Boyatzis, R. E. (2008). Competencies in the 21st century. https://doi.org/10.1108/02621710810840730

Burgoyne, J. (1989). Creating the managerial portfolio: Building on competency approaches to management development. Management Learning.

https://doi.org/10.1177/135050768902000109

Cernusca, L., \& Dima, C. (2007). Competency and Human Resource Management. Revista Da Faculdade de Ciências Humanas e Sociais, 162-171.

Concise Oxford Dictionary of Current English, Sykes, J.B., (ed) (1987) (7th edition) Oxford: Oxford University Press, pp. 191-192

Dirani, K. M., Abadi, M., Alizadeh, A., Barhate, B., Garza, R. C., Gunasekara, N., Ibrahim, G., \& Majzun, Z. (2020). Leadership competencies and the essential role of human resource development in times of crisis: a response to Covid-19 pandemic. Human Resource Development International. https://doi.org/10.1080/13678868.2020.1780078

Dubois, D., \& Rothwell, W. (2004). Competency-Based or a Traditional Approach to Training? $T \& D, 58(4), 46$.

Efimova, G. Z., Sorokin, A. N., \& Gribovskiy, M. V. (2021). Ideal teacher of higher school: Personal qualities and socio-professional competencies. Obrazovanie i Nauka. https://doi.org/10.17853/1994-5639-2021-1-202-230

Evarts. (1987). Enhancing managerial competence: the american management association competency programme. Journal of Management Development, 6(4), 7-18. https://doi.org/10.1108/09574090910954864

Frezza, S., Daniels, M., Pears, A., Cajander, Å., Kann, V., Kapoor, A., McDermott, R., Peters, A. Sabin, K. M., \& Wallace, C. (2018). Modelling competencies for computing education beyond 2020: A research based approach to defining competencies in the computing 
disciplines. Annual Conference on Innovation and Technology in Computer Science Education, ITiCSE. https://doi.org/10.1145/3293881.3295782

Hager, P., Gonczi, A., \& Athanasou, J. (1994). General Issues about Assessment of Competence. Assessment \& Evaluation in Higher Education, 19(1), 3-16. https://doi.org/10.1080/0260293940190101

Hoffmann, T. (1999). The meanings of competency. Journal of European Industrial Training, 23(6), 275-286. https://doi.org/10.1108/03090599910284650

Huei, O. K., Rus, R. C., \& Kamis, A. (2019). Need Analysis: Competency Development Measurement Instrument in Mastering the Content of Design and Technology Subject in High School. International Journal of Academic Research in Business and Social Sciences. https://doi.org/10.6007/ijarbss/v9-i6/6065

Kakemam, E., Liang, Z., Janati, A., Arab-Zozani, M., Mohaghegh, B., \& Gholizadeh, M. (2020). Leadership and management competencies for hospital managers: A systematic review and best-fit framework synthesis. In Journal of Healthcare Leadership. https://doi.org/10.2147/JHL.S265825

Kuijpers, M. A. C. T., Schyns, B., \& Scheerens, J. (2006). Career competencies for career success. Career Development Quarterly. https://doi.org/10.1002/j.21610045.2006.tb00011.x

McClelland, D. (1973). Testing for competence rather than for "intelligence". The American Psychologist, 28(1), 1-14. https://doi.org/10.1037/h0038240

Mohd Salleh, K., Sulaiman, N. L., \& Gloeckner, G. W. (2015). The development of competency model perceived by Malaysian human resource practitioners' perspectives. Asian Social Science, 11(10), 175-185. https://doi.org/10.5539/ass.v11n10p175

Moore, D. R., Cheng, M., \& Dainty, A. R. J. (2002). Competence, competency and competencies: performance assessment in organisations. Work Study. https://doi.org/10.1108/00438020210441876

Oberländer, M., Beinicke, A., \& Bipp, T. (2020). Digital competencies: A review of the literature and applications in the workplace. Computers and Education. https://doi.org/10.1016/j.compedu.2019.103752

Oise Delamare Deist, F. LE, \& Winterton, J. (2005). What Is Competence? Human Resource Development International, 8(1), 27-46. https://doi.org/10.1080/1367886042000338227

Prahalad, C. K., \& Hamid, G. (2007). The core competence of the corporation. In Software Management, Seventh (pdition 259-271). https://doi.org/10.1109/9780470049167.ch7

R.Yuvaraj. (2011). Competency Mapping : A Drive For Indian Industries. International Journal of Scientific \& Engineering Research.

Rothwell, W. J. (2002). Chapter 5: What are the roles, competence, and outputs of the workplace learner? In The workplace learner: how to align training initiatives with individual learning competencies (pp. xxvi, 358).

Shet, S. V., Patil, S. V., \& Chandawarkar, M. R. (2017). Framework for methodical review of literature on leadership competencies. Cogent Business and Management, 4(1), 1-12. https://doi.org/10.1080/23311975.2017.1309123

Spencer, L. M., \& Spencer, S. M. (1993). Competence at Work: Models for Superior Performance. In John Wiley \& Sons (pp. 1-372).

Suhairom, N., Musta'amal, A. H., Amin, N. F. M., \& Johari, N. K. A. (2014). The Development of Competency Model and Instrument for Competency Measurement: The Research 
Methods. Procedia - Social and Behavioral Sciences, 152, 1300-1308. https://doi.org/10.1016/j.sbspro.2014.09.367

Wong, S.-C. (2020). Competency Definitions, Development and Assessment: A Brief Review. International Journal of Academic Research in Progressive Education and Development. https://doi.org/10.6007/ijarped/v9-i3/8223

Woodruffe, C. (1991). Competent By Any Other Name. Personnel Management. 